American Journal of Environmental Sciences 2 (3): 104-108, 2006

ISSN 1553-345X

(C) 2006 Science Publications

\title{
Evaluation of Temperature Trend In Contaminated Tidal Flat In The Ariake Sea, Japan
}

\author{
${ }^{1}$ M.Azizul Moqsud, ${ }^{2}$ Shigenori Hayashi, ${ }^{2}$ Y. Jun Du, ${ }^{2}$ Daisuke Suetsugu \\ ${ }^{1}$ Civil Engineering Department, Saga University, 1 Honjo, Saga 840-8502, Japan \\ ${ }^{2}$ Institute of Lowland Technology, Saga University, 1 Honjo, Saga 840-8502, Japan
}

\begin{abstract}
Thermal environment of the tidal flat is one of the major parts of the contaminated geoenvironment of the Ariake Sea. The activities of marine ecosystem in tidal flats depend strongly on the thermal environment. In order to get a clear idea about the thermal environment of the tidal flats of the Ariake Sea, two study areas, Iida and Higashiyoka tidal flats were selected. By installing five nos. of thermocouple (Tokyo Sokki co., Model no.: N004853) at different specified depths ( $0.10 \mathrm{~m}, 0.20$ $\mathrm{m}, 0.50 \mathrm{~m}, 1.0 \mathrm{~m}$ and $2.0 \mathrm{~m}$ ) connected with data logger (TDS-530) were used to observe diurnal variation of temperature during the $1^{\text {st }}$ April to $8^{\text {th }}$ April, 2006 at Higashiyoka tidal flat. The measured temperature was stored automatically at $1 \mathrm{~h}$ interval in the data logger. To observe seasonal variation of temperature in different depths, temperature was measured by inserting the thermocouple at $0.10 \mathrm{~m}$ depths interval in the last week of every month at both study areas in the Ariake sea tidal flat. The diurnal temperature variation was more visible near the surface $(0.10 \mathrm{~m}$ and $0.20 \mathrm{~m})$ indicating the influence of solar radiation in that portion, however in the deeper region $(1.0 \mathrm{~m}$ and $2.0 \mathrm{~m}$ depth) the temperature was dominated by thermal properties of the mud. From seasonal variation of temperature it was seen that during spring and summer heat was transferred from subsurface to the deeper area but during winter and autumn opposite phenomenon was observed. A correlation is proposed to get the temperature profile in the tidal flat in different seasons.
\end{abstract}

Keywords: Diurnal, seasonal, temperature, tidal flat, variation

\section{INTRODUCTION}

The Ariake Sea which is situated in the south western part of Kyushu island, is one of the best-known semi-closed shallow seas in Japan. The vast muddy tidal flat of the Ariake Sea, which is almost $40 \%$ of the total tidal flat area of Japan, is famous for its rich fishery products and Porphyra sp. (sea weed) cultivation. However, a dramatic decrease of catch of shells, such as Sinonovacula constricta, Atrina pectinata and Crassostrea gigas is observed in the tidal flat in the Ariake Sea for the last 3 decades. According to Saga agricultural and forestry statistical society (SAFSS), Japan 2006, the conditions of Sinonovacula constricta, living in the depth of $0-0.70 \mathrm{~m}$ of the mud, was very bad as $1.7 \times 10^{5} \mathrm{~kg}$ catch in 1976 dropped to practically nil by 1992 . The cause for the declination of the fishery products is the unfavorable geoenvironmental condition of the Ariake Sea created by acid treatment practice for the Porphyra sp. (sea weed) cultivation ${ }^{[4,7]}$.During the period of the cultivation (December-March), the acid (which is mainly organic) is used as the disinfectant acid to treat the Porphyra sp. cultivated in the sea and also to provide some nutrient phosphorus to it. This organic acid provides ample of foods for the sulphate reducing bacteria living in the mud and consequently increase the sulphide content in the mud. The generation of sulphide is influenced by the seasonal temperature and shows a higher value during the summer and the late spring as bacteria becomes more active in the higher temperature ${ }^{[5,7]}$. Moreover, the activities of the benthos depend strongly on the temperature and thermal environment near the sediment surface ${ }^{[3]}$. Photosynthetic capacity of micro phytobenthos on an intertidal flat was also strongly influenced by mud surface temperature ${ }^{[2]}$. The filtration rate of bivalves was dependent on the water temperature ${ }^{[6]}$. Thermal properties dictate the storage and movement of heat in soils and as such influence the temperature and heat flux in soils as a function of time and depth ${ }^{[1]}$.So it is very important to get an idea about the thermal environment and temperature profile in the tidal flat. But as a matter of fact that, no study had been carried out before to get the information about the thermal properties or the temperature profile in the Ariake Sea tidal mud. So the objective of this study is to get the information of the temperature distribution in different depths and find a diurnal and seasonal trend of

Corresponding Author : M.Azizul Moqsud, Department of Civil Engineering, Saga University,1 Honjo Saga Shi, Japan Tel: 81-952-244822 Fax: 81-952-288189 
it in the tidal flat region, and finally propose a correlation with respect to depth for the temperature distribution in different seasons which can be used for the ocean thermal energy conversion research as well as for the regular monitoring of the geo-environmental conditions of the contaminated tidal flat.

\section{STUDY AREAS}

Two tidal flat areas in the Ariake Sea, Higashiyoka and Iida were selected as the study areas. Fig. 1 shows the locations of the two sites along with the different types of Porphyra sp. cultivation areas. The tidal currents sweep into the sea and move northwards along the eastern shoreline and create a counterclockwise water movement. This would sweep the finer suspended particles delivered by rivers on the east side towards the inland end, where sedimentation

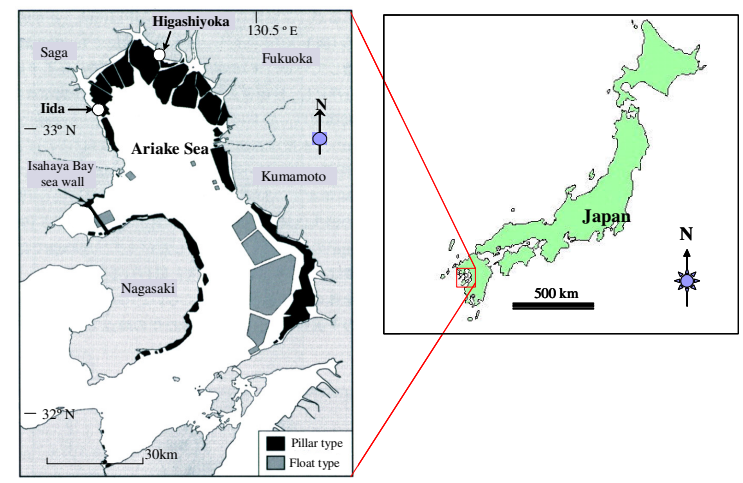

Fig. 1: Map of the Ariake Sea indicating the study areas and different types of Porphyra sp. cultivation Areas

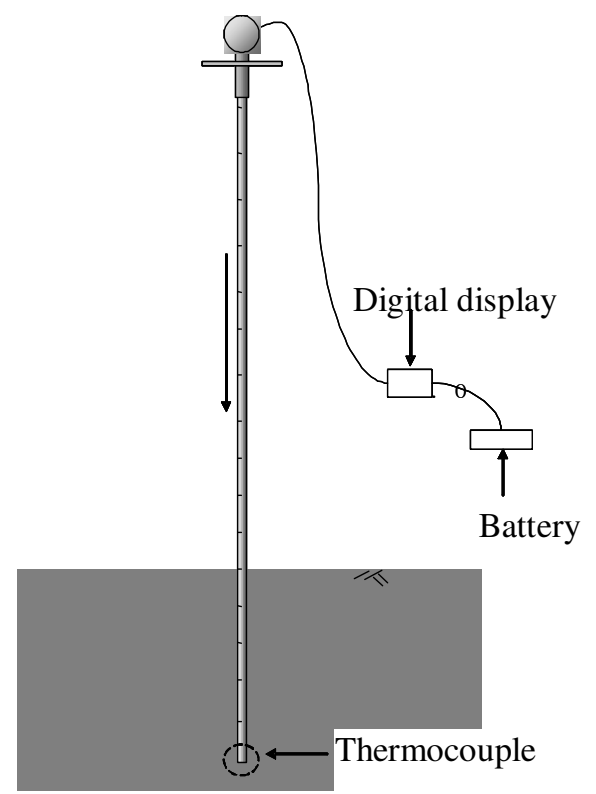

Fig. 2: Schematic diagram for thermocouple for measuring temperature at different depths
Table 1: Basic Physicochemical properties of Iida and Higashiyoka tidal flat

\begin{tabular}{|c|c|c|}
\hline $\begin{array}{l}\text { Physicochemical } \\
\text { parameters }\end{array}$ & $\begin{array}{l}\text { Iida tidal } \\
\text { mud }\end{array}$ & $\begin{array}{l}\text { Higashiyoka } \\
\text { tidal mud }\end{array}$ \\
\hline Density $\left(\right.$ x $\left.10^{-3} \mathrm{~kg} / \mathrm{m}^{3}\right)$ & 2.69 & 2.71 \\
\hline Water content (\%) & 235 & 168 \\
\hline Liquid limit $\mathrm{w}_{\mathrm{L}}(\%)$ & 150 & 130 \\
\hline Plasticity Index Ip & 87 & 73 \\
\hline Ignition Loss (\%) & 13.3 & 11.9 \\
\hline $\mathrm{pH}$ & 7.92 & 8.03 \\
\hline $\mathrm{ORP}(\mathrm{mV})$ & -95.4 & -40.7 \\
\hline $\begin{array}{l}\text { AVS (x } 10^{-3} \mathrm{~kg} / \mathrm{kg} \text {-dry } \\
\text { mud) }\end{array}$ & 0.42 & 0.16 \\
\hline Salinity $\left(\mathrm{kg} / \mathrm{m}^{3}\right)$ & 16 & 17 \\
\hline \multicolumn{3}{|l|}{ Grain size analysis (\%) } \\
\hline Sand & 7 & 9 \\
\hline Silt & 30 & 36 \\
\hline Clay & 63 & 55 \\
\hline
\end{tabular}

would occur ${ }^{[8]}$. Higashiyoka $\left(33.18^{\circ} \mathrm{N}, 130.26^{\circ} \mathrm{E}\right)$, located in the bay head was chosen as a study area which is near to Chikugo river as well as other rivers and thought to be affected by the river waters. Another study area was Iida $\left(33.57^{\circ} \mathrm{N}, 130.40^{\circ} \mathrm{E}\right)$, which seems to be the most affected by the acid treatment practice. The typical values of basic physicochemical properties of the Iida and Higashiyoka tidal mud are tabulated in the Table 1.The mud samples were collected from the $0-0.20 \mathrm{~m}$ in the Ariake tidal mud.

\section{MATERIALS AND METHODS}

\section{FIELD OBSERVATIONS}

The vast tidal flat area of the Ariake Sea, which is $40 \%$ of the total tidal area of Japan, is mainly muddy with high water content. The percentage of clay content is much higher than the sand or silt. To evaluate the temperature variation in different depths of the tidal mud, 5 nos. of thermocouples (Tokyo Sokki Kenkyojo Co., Ltd. Model no.: N004853) were installed at 0.10 $\mathrm{m}, 0.20 \mathrm{~m}, 0.50 \mathrm{~m}, 1.0 \mathrm{~m}$, and $2.0 \mathrm{~m}$ depth which were connected with data logger (TDS-530) to store the continuous hourly data of the temperature at Higashiyoka tidal flat. The sensors were placed about $20 \mathrm{~m}$ away from the shore line .The data loggers were kept in a watertight box and put in a small ship which was tied with some anchor and moved upward and 
downward during the high tide and ebb tide, respectively. Every two days the automatically stored data was collected from the data logger in the ship. This field investigation was carried out from $1^{\text {st }}$ April, 2006 to $8^{\text {th }}$ April, 2006 at Higashiyoka tidal flat. For seasonal temperature variation measurement, every month in the last week, the data were collected from both Iida and
Higashiyoka tidal flat, $20 \mathrm{~m}$ away from the shore line during the ebb tide. By inserting the thermocouple (2.50 $\mathrm{m}$ long, $0.096 \mathrm{~m}$ diameter) vertically into the tidal flat up to $2.0 \mathrm{~m}$ depth and at each $0.10 \mathrm{~m}$ interval the data was measured. The thermocouple was connected with a battery and a digital display. The temperature data was displayed directly in degree celcius (Fig.2). Field

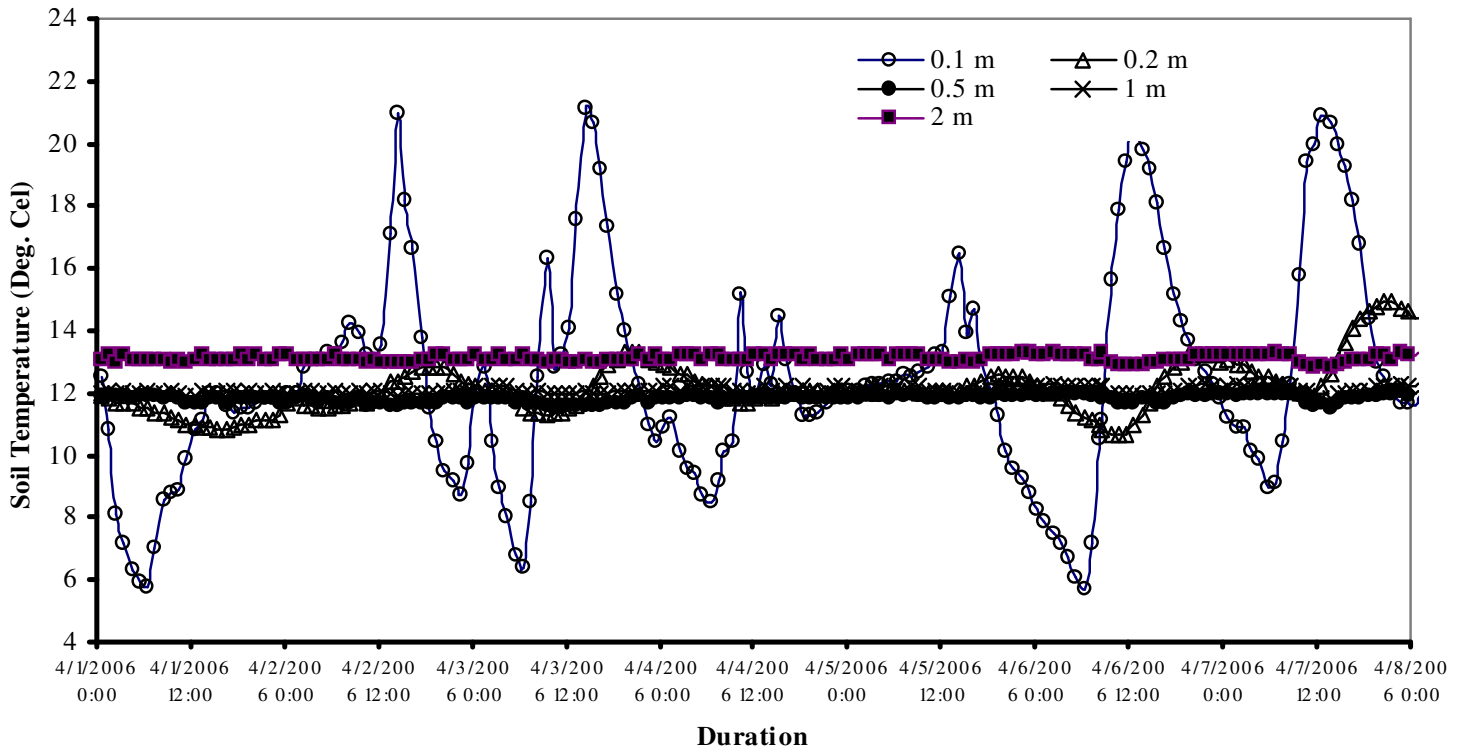

Fig. 3: Variation of temperature in different depths at Higashiyoka tidal flat during $1^{\text {st }}$ April to $8^{\text {th }}$ April,2006

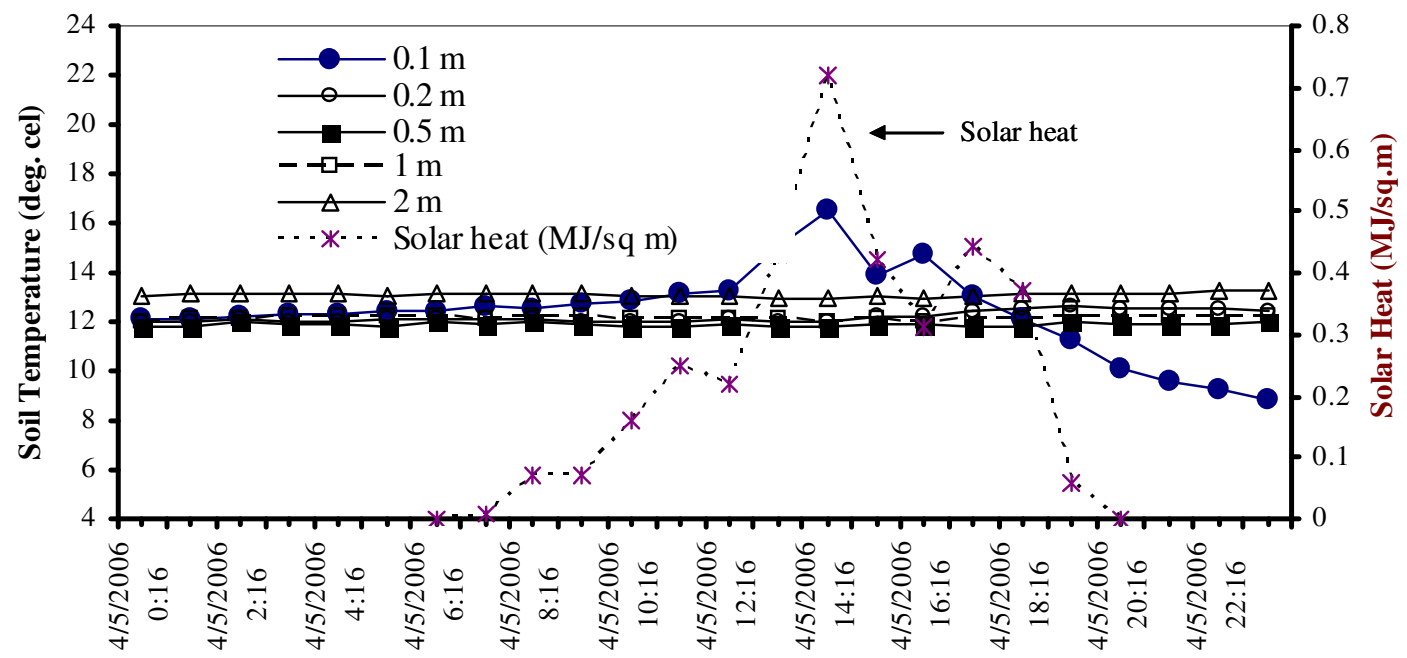

Duration

Fig. 4: Variation of one day ( $24 \mathrm{~h})$ temperature in different depths at Higashiyoka tidal flat showing the influence of solar radiation to the diurnal variation 
investigation for collecting data was carried out from September 2005 to July 2006 to observe the seasonal variation of temperature in the tidal mud.

\section{RESULTS AND DISCUSSION}

Figure 3 shows the variation of the tidal mud temperature in different depths from $1^{\text {st }}$ April, 2006 to $8^{\text {th }}$ April, 2006. It is seen that at $0.10 \mathrm{~m}$ and $0.20 \mathrm{~m}$ depth, the fluctuation of temperature was more prominent. However, from $0.50 \mathrm{~m}$ to $2.0 \mathrm{~m}$ depth, the diurnal variation was not so prominent. In the subsurface region, the solar radiation affected the soil temperature more than the deeper part of the tidal mud. This type of diurnal trend of temperature also agrees with the findings in Baeksu tidal flat in Korea ${ }^{[9]}$. At 2.0 $\mathrm{m}$ depth, the temperature shows higher value than $1.0 \mathrm{~m}$ depth. This is probably due to the volumetric heat capacity of the tidal mud and the time lag for absorbing and releasing the heat during the summer and the

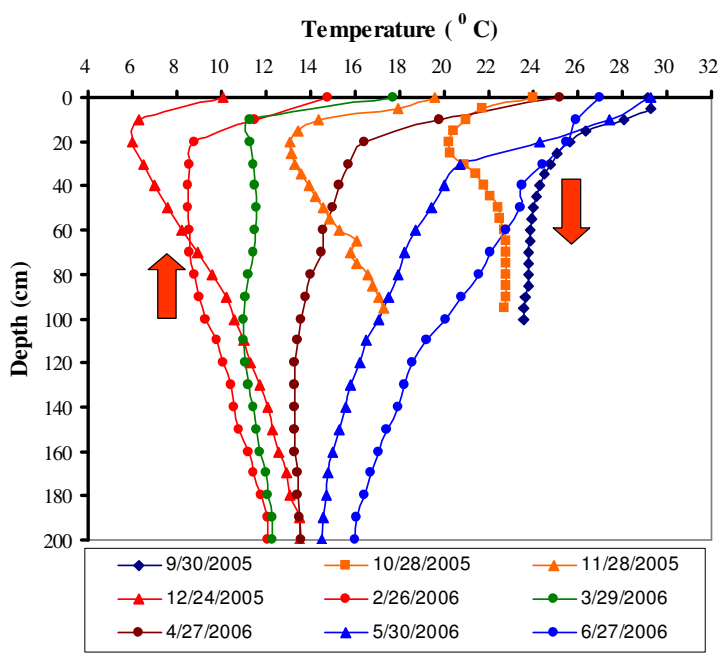

Fig. 5: Variation of temperature at different depths in different months at Higashiyoka tidal flat showing the heat flux transfer direction

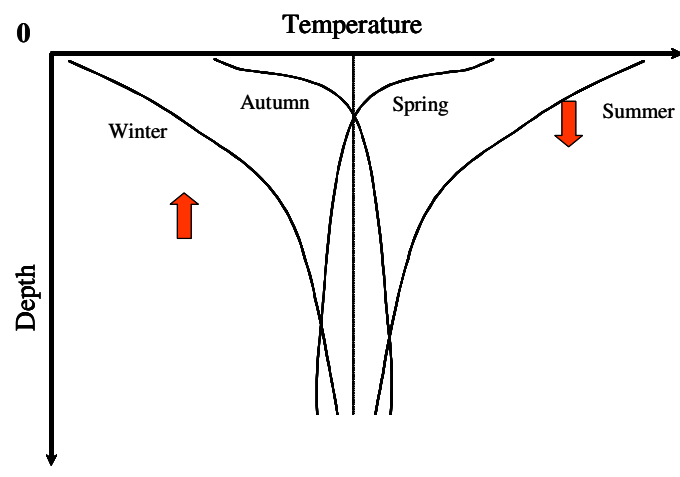

Fig. 6: Schematic model of temperature profile at different depths as it varies in different seasons in the Ariake tidal flat winter. The peak temperature reached at different time at different depths. During the ebb tide the time lag to reach the peak in different depths is more than the high tide due to infiltration of sea water in the deeper depth.

Figure 4 shows one day $(24 \mathrm{~h})$ variation of tidal mud temperature influencing by the solar radiation. It is seen that at $0.1 \mathrm{~m}$ depth, the peak value reached when the solar radiation was also peak. At night, the temperature did not show any variation both in the ebb tide and the high tide time. This proves that the tidal mud temperature is only influenced by the solar radiation in the subsurface region. The tidal mud temperature at subsequent depths reaches the peak at different timings, with the time lag increasing with depth. The peak temperature reached about 2:00 PM and the value was about $17{ }^{0} \mathrm{C}$ at $0.10 \mathrm{~m}$. The temperature at $0.50 \mathrm{~m}, 1.0 \mathrm{~m}$ and $2.0 \mathrm{~m}$ remained almost constant around $12-13{ }^{\circ} \mathrm{C}$. It is concluded from this Fig. that time lag increased with increasing depth but the rate of increasing decreased with the increasing depth. Thermal properties of tidal mud govern this type of phenomenon.

Figure 5 shows that the seasonal variation of temperature at different depths at Higashiyoka tidal mud. During the spring and summer the surface temperature shows a higher value than the subsequent depths. During this time, heat was absorbed by the tidal mud and heat was transferred from the surface to the deeper part of the tidal mud. On the other hand, during the winter and autumn the surface temperature was lower than the subsequent depths. During this time heat is released to the surface. During April, the variation was not so prominent. It showed almost straight line. Iida site also showed the same trend as with Higashiyoka site during the summer and the winter.

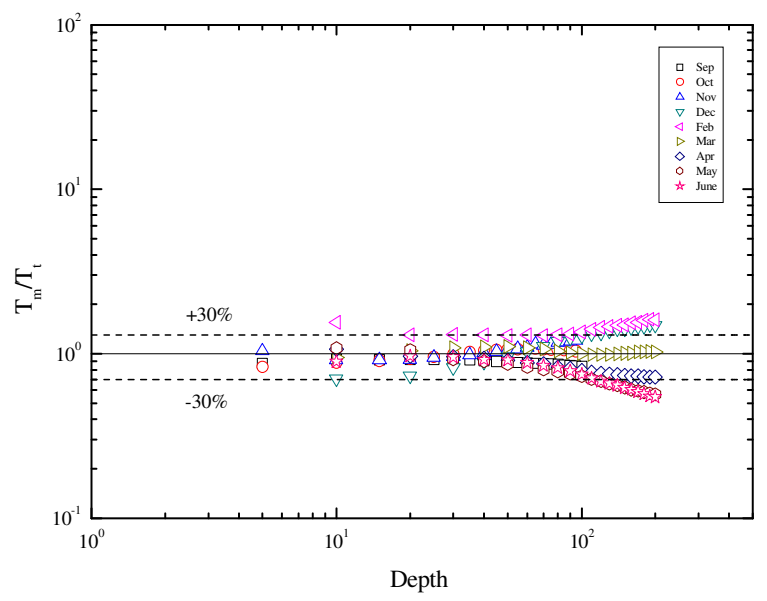

Fig. 7: Ratio of Measured and theoretical temperature Vs depth 
Figure 6 shows that the schematic model of temperature profile at different depths as it varies in different seasons in the tidal flat in the Ariake Sea, Japan. The arrow directions indicate the heat transfer direction inside the tidal flat in different seasons.

To get a view of the temperature profile inside the tidal flat mud a correlation is proposed. The proposed correlation is an expo-linear equation. By using the average temperature of atmosphere one can find the temperature at different depths inside the tidal flat area.

$$
\frac{T_{d}}{T_{a v g}}=0.57 e^{(-d / 9.83)}+0.0012 d+1.12
$$

Where $\mathrm{T}_{\mathrm{d}}=$ Temperature at any depth in degree celcius

$\mathrm{T}_{\mathrm{avg}}=$ Average atmospheric temperature at any month in degree celcius $\mathrm{d}=$ depth in centimeter

The average atmospheric temperature is provided by the local weather office for a particular month in a particular area.

Figure 7 shows the relation between the ratio of measured and the theoretical temperature and depths. It is seen that almost $90 \%$ data are in the $30 \%$ error. However, below $1.0 \mathrm{~m}$ depth it shows more deflection than $30 \%$ of error. This is due to the fact that in that region the thermal properties affected the temperature. Present research is going on to incorporate the thermal properties values in that correlation.

\section{CONCLUSIONS}

The diurnal temperature variation is more visible near the surface $(0.10 \mathrm{~m}$ and $0.20 \mathrm{~m})$. The temperature increases gradually from morning, peak at noon and gradually decreases at afternoon. However, at $1.0 \mathrm{~m}$ and $2.0 \mathrm{~m}$ depth, the variation of temperature was not so prominent. This is due to the volumetric heat capacity and the thermal conductivity of the tidal mud. From the seasonal variation of temperature it is seen that during late summer, the surface and subsurface temperature is always higher than the deeper depth of the mud while in the winter the opposite phenomenon occurs. The proposed correlation for measuring temperature profile in different depths can be used in the ocean thermal energy conversion research and also be a useful tool for the regular monitoring of the contaminated geo-environmental conditions in the tidal flat.

\section{REFERENCES}

1. Anandkumar K., R.Venkatesan and T Prabha., 2001. Soil thermal properties at Kalpakkam in coastal south India. Earth Planet Science, 110 (3): 239-245.

2. Blanchard G.F., P. Guarini and P. Richard, 1997. Seasonal effect on the relationship between the photosynthetic capacity of intertidal microphytobenthos and temperature. Journal of Phycol., 33:723-728.

3. Guarini, J.M., Balanchard, G.F., Gros, Ph., Harrison,S.J., 1997. Modeling the mud surface temperature on intertidal flats to investigate the spatio-temporal dynamics of the benthic micro algal photosynthetic capacity. Marine Ecological Progress Series, 53: 25-36.

4. Hayashi S. and Du Y.J., 2005. Effect of acid treatment agent of sea laver on geo-environmental properties of tidal flat muds in the Ariake Sea. Journal of ASTM International, Vol.3, No.4 (in press)

5. Holmer, M and P. Storkholm, 2001. Sulphate reduction and sulphur cycling in lake sediments: a review. Freshwater Biology, 46:431-451.

6. Hosokawa Y, Kiebe E.,Miyoshi Y.,Kuwae T. and Furukawa K. 1996. Distribution of aerial filtration rate of short-necked clam in coastal tidal flat. The technical note of the port and harbor research institute, 844: 21 (in Japanese with abstract in English).

7. Moqsud M.A., Hayashi S., Du Y.J., Suetsugu D., Ushihara Y., Tanaka S. and Okuzono K. 2006. Effects of acid treatment on geo-environmental conditions in the Ariake Sea, Japan. The 21st ICSW, March 26-29. Philadelphia, USA.

8. Ohtsubo M., Egashira K. and Kashima K. 1995. Depositional and post depositional geochemistry and its correlation with geotechnical properties of the marine clays in Ariake bay. Geotechnique, 45: 509- 523.

9. Yang-Ki C., Kim T.,You, K., Park, L., Moon, H., Lee,S., Youn,Y., 2005. Temporal and spatial variability in the sediment temperature on the Baeksu tidal flat, Korea. Estuarine coastal and shelf science, 65:302-308. 